\title{
The quality of corporate governance in South Africa: comparing the parastatal and listed industrial sectors
}

\author{
Mike F. van Wyk \\ Box 86, Fontainebleau 2032, South Africa
}

Received May 1999

\begin{abstract}
The quality of corporate governance service in the parastatal (also called public entity) and listed industrial company sectors of the South African economy was assessed. The assessment was done using newly developed service quality assessment instruments. The reliability of the findings on the quality of corporate governance service implied a $99.5 \%$ probability that the sample mean did not differ from the population mean by more than 0.2 on a seven-point scale. In both sectors the actual corporate governance service was assessed against two levels of expectation, namely the desired service level and the lowest acceptable service level. The instruments were the same except for a few adaptations to cater for the less stringently legislated listed company sector and to provide for insights gained from the first assessment. Both assessments resulted in the same four dimensions, namely 'directing and monitoring', 'board capacity'. 'assurance' and 'responsiveness and reliability'. One fundamental difference was reported, namely that the listed company directors' corporate governance was in total, in all four dimensions and on all criteria assessed as between the lowest acceptable and the desired service levels. The public entity directors' corporate governance service was in total, in all four dimensions and on all criteria assessed as below the desired as well as the lowest acceptable service levels. The standard deviations as reported were such that it has to be concluded that acceptable and unacceptable corporate governance service levels are found in public entities as well as in listed companies. The assessment results are reported below graphically. Three criteria appeared on both assessments' lists of ten worst-assessed criteria. They were directors 'being always properly prepared for meetings'. 'doing their homework thoroughly' and 'displaying impeccable integrity and honesty, for example with their own claims .
\end{abstract}

\section{Introduction}

During the past decade or so the role of corporate governance in the success or failure of entities has become increasingly prominent. Researchers, mainly after scandals, consistently report (Butler, 1991: 24; Daily \& Dalton, 1994: 647; Finkelstein \& Boyd, 1998: 179; Melville-Ross, 1996: 54; Pearce, 1991: 157) correlations between success and good governance practices' and between failure and 'bad governance practices'. Sometimes recommendations (Corrin, 1993: 81) are not based on finding of correlations but on logic or personal opinion. Pleas (Millstein, 1997: 10, Sanders \& Carpenter, 1998: 164; and Singleton-Green, 1993: 45) before, during and after interventions to advance good governance practices, continue. Examples of the numerous commissions and committees used to investigate corporate governance are the Treadway Commission (1987) in the United States, the Cadbury Commission (1992) in the United Kingdom and the King Committee (1994) in South Africa. Over time good governance commissions have resulted in voluntary and sometimes not so voluntary compliance with good governance practices. Although the wisdom of national and universal standardization of good governance practices is still hotly debated, research (De Castro, 1998: 23; Conner, 1995: 19; Bryne, 1996: 64) indicates increased compliance with such practices.

Scientific assessment of the quality of corporate governance as opposed to the level of compliance with good governance standards, remains largely unreported. Two research projects in South Africa may shed some light on the quality of corporate govemance in South Africa. In the first study (Van Wyk, 1998) the author assesses the quality of corporate governance in South African state-funded entities, called public entities, as practiced by these entities' directors. Public entity directors are, almost without exception, non-executive. In his second study the author assesses the quality of corporate govemance in the industrial sector of companies listed on the Johannesburg Stock Exchange. Listed company directors comprise a mix of executive and non-executive people.

\section{An instrument to assess the quality of the corporate governance service}

A fundamental premise in the assessment of the quality of corporate govemance is that corporate governance entails the rendering of a service. In the case of companies the directors render the corporate governance service to shareholders as the main clients. In the case of public entities the taxpayer is the main client. The service involved in governing corporations meets the criteria of Parasuraman et al. (1988: 13) for qualifying as a service, namely intangibility, heterogeneity. and the inseparability of production and consumption.

A recent literature review of service measurement instrtments revealed that there was no instrument specifically designed and used to evaluate the quality of corporate governance service, whether in commercial companies or in public entities. Extensive use of a service quality assessment instrument called SERVQUAL was however reported (Babakus \& Boller, 1992: 253-268; Carman, 1990: 33-55; Chaston, 1995: 332-349; Cronin \& Taylor, 1994: 125-131: Herbert, 1994: 3-21; Kettinger \& Lee, 1994: 737-767; Parasuraman et al., 1988: 12-40; Parasuraman et al., 1991: 420450; P ırasuraman et al., 1993: 140-147; Parasuraman et al. 1994: 111-124; Parasuraman et al., 1994: 201-230; Pitt et al. 1995: 173-187; Teas, 1994: 132-139; White \& Abels, 1995: 36-45). In all areas of SERVQUAL's application the assessments were done by people (some internal) with first-hand experience of the quality of the service rendered. 
Shareholders and taxpayers do not attend board meetings and are therefore ill equipped to assess the quality of corporate governance service. It was concluded that the methodology used in the development of SERVQUAL (Parasuraman et al., 1988: 12-40), namely Churchill's paradigm for developing better measures, resulted in a reliable instrument that could be used to develop an instrument for assessing corporate govemance service.

Churchill (1979: 67) stresses the importance of specifying the domain of research. For the purposes of the development of this assessment instrument, the domain was specified as satisfaction with corporate governance service. Satisfaction was defined as incorporating the three levels discussed by Parasuraman et al. (1994: 209-228). These are the expected service level, the lowest acceptable service level and the actually experienced service level. In generating criteria items to capture the specified domain (Parasuraman et al., 1988: 38), SERVQUAL's items for assessing service in general were supplemented with items identified through a literature review of corporate governance. In addition to these items and the 22 SERVQUAL items, items submitted by experts in The Institute of Directors' training videos were used to develop an item bank for consideration by a panel of researchers from the Human Sciences Research Council (HSRC). This HSRC panel's input resulted in the elimination of some SERVQUAL items, and an initial instrument with 55 items was subsequently used for scale purification with the public entities. A marginally revised instrument with 54 items was later used with the listed companies. This revision was undertaken to accommodate the different nature of the listed companies.

\section{Public entity survey}

Some two years prior to the survey the Minister of Finance instructed a total of twenty entities (SAICA, 1995) to comply with prescribed good governance practices. In the year preceding the survey these public entities had a combined turnover of R55 billion and they were used as the population for the purposes of the survey. Approximately 140 executives in these public entities regularly attended board meetings but were not directors themselves. Ninety-seven of these executives were requested to assess the quality of the corporate governance service rendered by their boards and 49 eventually responded.

The 49 responses were processed and the scale was purified in accordance with Churchill's (1979: 69) recommendations. Several rounds of computing coefficient alphas (on the expected minus experienced service level scores), eliminating items with low corrected item-to-total correlations and oblique factor analysis in terms of the OBLIMIN procedure in SPSS were done. In accordance with Parasuraman et al. (1988: 20) some items were reassigned to other dimensions, and by repeating the item-deletion and reassigning process several times the number of items was reduced to 31 , representing four distinct dimensions.

After executing the above procedure the alpha values ranged between 0.84 and 0.95 in the four dimensions, with factor loadings ranging between 0.42 and 0.93 . The average pairwise correlation between the four factors following oblique rotation was 0.29 , and in all three of the above areas (alpha values, factor loadings and pairwise correlation) the results were similar to or better than those achieved by Parasuraman et al. (1988: 24). Churchill (1979: 68) reports that Nunally proposed alphas between 0.50 and 0.60 for similar early-stage basic research and states that increasing alphas beyond 0.80 is regarded as wasteful.

The final four dimensions with their concise definitions were as follows:

- Directing and monitoring: giving direction to and monitoring the entity;

- Board capacity: having the capacity to execute the corporate governance;

- Responsiveness and reliability: having the willingness and dependability to act;

- Assurance: caring for the stakeholders.

The reliability of linear combination (total scale reliability) was 0.96 . This alpha again substantially exceeds the 0.90 required by Churchill (1979: 68) for applied research as well as his 0.95 requirement for reliability for basing important decisions on. The percentage variance extracted by the four factors was 70.3 .

\section{Listed industrial companies survey}

For the purposes of this assessment the Financial Mail's 1997 (363-366) Top Companies Survey was used. The company secretaries of the 200 largest (ranked by turnover and with a total annual tumover of over R500 billion) listed industrial companies were requested to assess the quality of their board's corporate governance service. Sixty secretaries eventually responded. The assessment was done with a minimally revised instrument (to accommodate the different nature of the listed companies) consisting of 54 items.

After executing the procedures described above as for the public entities, the alpha values ranged between 0.86 and 0.95 in the four dimensions, with factor loadings ranging between 0.31 and 0.83 . The average pairwise correlation between the four factors following oblique rotation was 0.39 and in all three of the above areas (alpha values, factor loadings and pairwise correlation) the results were again similar to or better than those achieved by Parasuraman et al. (1988: 24). Thirty-six items remained in the instrument and the final four dimensions with their concise definitions were the same as for the public entities.

The reliability of linear combination (total scale reliability) was 0.965 . This alpha again substantially exceeds the 0.90 required by Churchill (1979:68) for applied research as well as his 0.95 requirement for reliability for basing important decisions on. The percentage variance extracted by the four factors was 65.7 .

\section{Validity}

The final assessment instruments used for assessing the public entities and the listed companies are attached as Annexures 1 and 2. After finalizing the two instruments and verifying their content validity, a review of both instruments was done to ensure that they measured what they were supposed to measure and that they measured all the important facets of the domain. The items that had been dropped from the instruments to increase reliability were checked against those remaining in the instruments and against the expert opinions to ensure that the level of content validity required 
by Parasuraman et al. (1988: 28) was met. In addition and for the same purpose, the items remaining in the instrument were checked for completeness against the literary review. Twentynine of the 31 items in the final public entity instrument again featured among the 36 items that survived the reliability purification of the listed company instrument.

In assessing SER VQUAL's convergence validity, Parasuraman et al. (1988:28) measured the correlation between the responses to the SERVQUAL scores and to a question that provided an overall rating of the service under evaluation. This was also done for both new instruments. Regarding correlation with measures of other related variables, the respondents to the public entity instrument were asked to rate the corporate governance service's overall quality by marking one of the four words 'poor', 'fair', 'good' and 'top'. The correlation between this rating of overall quality and the scores was examined using a one-way analysis of variance with the categories 'poor' and 'fair' combined. Separate analyses of variance were conducted for the total scale and for each dimension, with the differences between desired and actual and between lowest acceptable and actual scores acting as dependent variables during separate runs. Duncan's (Parasuraman et al., 1988: 29) multiple-range test was then applied to further investigate the analysis of variance results. Statistically significant different averages were found between the top/good and the fair/poor categories but not between the top and good or fair and poor categories. The full findings are reported in Annexure 3.

In both final instruments validity was assessed (following Churchill, 1979: 70 and Parasuraman et al., 1988: 30) by determining whether the construct being evaluated was empirically associated with the measures of other conceptually related variables. The respondents were asked two general questions (marked 'Recommend' and 'Problem' in Annexure 4 for the public entities and 'Recommend' and 'Queried' in Annexure 4 for the listed companies) that were expected to correlate conceptually with perceived quality. If the respondents answered 'yes' to the question 'would you recommend the board for appointment at another company' and 'no' to the question 'have you ever seriously questioned the board's governance', such a board was hypothesized to render better service quality than others.

With the public entities it was found that in all four dimensions and on the combined scale the mean responses of the respondents willing to recommend their boards were significantly different from the mean responses of the respondents not willing to recommend their boards. This was the case on both levels of satisfaction, namely expected minus actual and lowest acceptable minus actual service levels. The mean responses of the respondents who had seriously questioned their boards were for the combined scales at both levels of satisfaction, namely expected minus actual and lowest acceptable minus actual service levels, significantly different from the responses of the respondents who had not seriously questioned their boards. At both service levels this significant difference was observed for five of the eight dimensions. These findings are similar to those of Parasuraman et al. (1988: 30) and meet Churchill's (1979: 70) requirement of responses correlating with other measures of the same variable. It was therefore concluded that the strength and persistence of the linkages between overall quality and this instrument's scores clearly indicated that the instrument's convergence validity was equal to that of SERVQUAL.

With the listed companies it was also found that in all four dimensions and on the combined scale the mean responses of the respondents willing to recommend their boards were sig. nificantly different from the mean responses of the respondents not willing to recommend their boards. This was the case on both levels of satisfaction, namely expected minus actua and lowest acceptable minus actual service levels. The mean responses of the respondents who had seriously questionet their boards were for the combined scales at the lowest acceptable minus actual level of satisfaction significantly different from the responses of the respondents who had not seriously questioned their boards but not at the expected minus actual level. At the lowest minus actual service level this significant difference was observed for all four dimensions, but at the expected minus actual service level for only one of the four dimensions. These findings are similar to those of Parasuraman et al. (1988: 30) and meet Churchill's (1979: 70) requirement of responses correlating with other measures of the same variable. It was therefore concluded that the strength and persistence of the linkages between overall quality and this instrument's scores clearly indicated that the instrument's convergence validity was equal to that of SERVQUAL.

\section{Results: the quality of corporate governance in pub. lic entities}

The findings of the assessment of the quality of corporate governance in public entities are fully set out in Annexure 5 .

The respondents indicated, on a seven-point scale for the overall instrument, a mean desired service level of 6.3 (standard deviation 0.4). The item with the highest desired service level was 'displaying impeccable integrity and honesty', with a mean score of 6.9 and a standard deviation of 0.3 . The item with the lowest desired service level was 'delivering tangible benefits by knowing important people', with a mean score of 5.6 and a standard deviation of 1.4. The dimension 'board capacity' recorded the highest desired mean score of 6.5 (standard deviation 0.5 ), with the remaining three dimensions all recording desired mean scores of 6.3 .

The respondents indicated, on a seven-point scale for the overall instrument, a mean lowest acceptable service level of 5.3 (standard deviation 0.8 ). The item with the highest mean score on this lowest acceptable service level was 'displaying impeccable integrity and honesty', with a mean score of 6.4 and a standard deviation of 0.8 . The item that scored the lowest in this category was 'delivering tangible benefits by knowing important people', with a mean score of 4.5 and a standard deviation of 1.5. The dimension 'board capacity' recorded the highest lowest acceptable mean score of 5.7 (standard deviation 0.7 ) with 'directing and monitoring' second (mean score 5.3 and standard deviation 0.8 ), 'assurance' third (mean score 5.2 and standard deviation 0.8 ) and 'responsiveness and reliability', lowest (mean score 5.0 and standard deviation 0.9)

The respondents indicated, on a seven-point scale for the overall instrument, a mean actual service level of 4.4 (standard deviation 1.0). The item with the highest experienced service level was 'ensuring that sound financial controls are 
in place', with a mean score of 5.4 and a standard deviation of 1.4. The item with the lowest experienced service level was 'utilizing the best external advice and assistance', with a mean score of 4.0 and a standard deviation of 1.2. The dimension 'board capacity' recorded the highest experienced mean score of 4.8 (standard deviation 1.1), with 'directing and monitoring' second (mean score 4.5 and standard deviation 1.0 ), and 'assurance' third (mean score 4.4 and standard deviation 1.1). 'Responsiveness and reliability' received the lowest mean score of 4.2 , with a standard deviation of 1.2 .

Parasuraman et al. (1994: 202) recommend that service be assessed by subtracting the desired service level from the experienced service level. This should be done not only for each item but also for each dimension and for the overall instrument, with the answer called the measure of service superiority (MSS). In items and dimensions where this measure gives a positive answer the experienced service level exceeds the desired service level. In items and dimensions where this measure gives a negative answer the experienced service level is lower than the desired service level.

The calculated MSS for the overall assessment resulted in a mean service level of -1.9 (standard deviation 1.0). This implies that the mean experienced service fell short of the expected service by 1.9 when measured on a seven-point scale. Without exception the service level in all items fell short of the desired expectation when the MSS was used. The item with the least negative score was 'ensuring that sound financial controls are in place', with a mean score of -1.1 and a standard deviation of 1.3. Three items recorded the same third most negative score of -2.3 , namely 'adding value through their strategic guidance' (standard deviation 1.3), 'promptness in taking governance action' (standard deviation 1.5) and 'governing continually and not only when convenient' (standard deviation 1.5). The item 'dependability in handling stakeholder's problems' recorded the second most negative score of -2.4 , with a standard deviation of 1.5 . The item 'having the knowledge to optimally govern' recorded the most negative score, namely -2.5 with a standard deviation of 1.7 . Regarding dimensionality, without exception the service level in all four dimensions fell short of the desired expectation when the MSS was used. The dimension with the least negative score was 'board capacity', with a mean score of -1.6 and a standard deviation of 1.1. The dimension with the second least negative score was 'directing and monitoring', with a mean score of -1.8 and a standard deviation of 1.1. The dimension with the second highest negative score was 'assurance', with a mean score of -1.9 and a standard deviation of 1.2. The dimension with the highest negative score was 'responsiveness and reliability', with a mean score of -2.1 and a standard deviation of 1.2 .

Parasuraman et al. (1994: 202) recommend that service further be assessed by subtracting the lowest acceptable service level from the experienced service level. This should be done not only for each item but also for each dimension and for the overall instrument, with the answer called the measure of service adequacy (MSA). In items and dimensions where this measure gives a positive answer the experienced service level xceeds the lowest acceptable service level. In items and dimensions where this measure gives a negative answer the ex- perienced service level is lower than the lowest acceptable service level.

The calculated MSA for the overall assessment resulted in a mean service level of -0.9 (standard deviation 1.2). This implies that the mean experienced service fell short of the lowest acceptable service by 0.9 when measured on a seven-point scale. Without exception, when measured against this lowered standard, the service level in all items still fell short of the lowest acceptable expectation when the MSA was used. The two items that had the same least negative mean score of -0.2 were 'delivering tangible benefits by knowing important people' (standard deviation 2.0) and 'willingness to help stakeholders' (standard deviation 1.4). Three items recorded the same third most negative score of -1.1 , namely 'disallowing each other private, hidden agendas' (standard deviation 1.6), 'promptness in taking governance action' (standard deviation 1.8) and 'governing continually and not only when convenient' (standard deviation 1.9). Two items recorded the same second most negative mean score of -1.2 , namely 'having the confidence of stakeholders' (standard deviation 1.5) and 'being always properly prepared for meetings' (standard deviation 1.7). The item having the knowledge to optimally govern' recorded the most negative mean score, namely -1.5 , with a standard deviation of 1.8. Regarding dimensionality, without exception the service level in all four dimensions fell short of the desired expectation when the MSA was used. Three dimensions recorded the same negative mean score of -0.8 , with 'directing and monitoring' and 'board capacity' having standard deviations of 1.2 and 'assurance' having a standard deviation of 1.4. The dimension with the highest negative score was 'responsiveness and reliability', with a mean score of -1.5 and a standard deviation of 1.8 .

\section{Results: the quality of corporate governance in listed industrial companies}

The findings of the assessment of the quality of corporate governance in listed industrial companies are fully set out in Annexure 5.

The respondents indicated, on a seven-point scale, an overall mean desired service level of 6.2 (standard deviation 0.5 ). The two items with the highest desired service level of 6.8 were 'displaying impeccable integrity and honesty', with a standard deviation of 0.6 , and 'preventing the CEO from misleading the board', with a standard deviation of 0.4 . The item with the lowest desired service level was 'serving on the board for an optimal period only', with a mean score of 5.1 and a standard deviation of 1.4. The dimensions 'assurance' (standard deviation 0.5 ) and 'responsiveness and reliability' (standard deviation 0.6 ) recorded the highest desired mean score of 6.4, with 'directing and monitoring' recording 6.3 (standard deviation 0.5 ) and 'board capacity' recording 5.9 (standard deviation 0.7 ).

The respondents indicated, on a seven-point scale for the overall instrument, a mean lowest acceptable service level of 4.9 (standard deviation 0.8 ). The item with the highest mean score on this lowest acceptable service level was 'displaying impeccable integrity and honesty', with a mean score of 6.1 and a standard deviation of 1.2. The item that scored the lowest in this category was 'serving on the board for an optimal period only', with a mean score of 3.7 and a standard 
deviation of 1.5. The dimension 'responsiveness and reliability' recorded the highest mean score on this lowest acceptable scale, namely 5.1 (standard deviation 1.0) with 'directing and monitoring' and 'assurance' (standard deviations both 0.9 ) recording a mean score of 5.0 and 'board capacity' recording the lowest score (mean score 4.6 and standard deviation 1.0).

The respondents indicated, on a seven-point scale, an overall mean actual service level of 5.4 (standard deviation 0.9 ). The item with the highest experienced service level was 'displaying impeccable integrity and honesty', with a mean score of 6.4 and a standard deviation of 1.2. The item with the lowest experienced service level was 'providing diversity through biographical composition', with a mean score of 4.1 and a standard deviation of 1.2. The dimension 'responsiveness and reliability' recorded the highest experienced mean score of 5.7 (standard deviation 0.7 ), with 'directing and monitoring' (standard deviation 0.9) and 'assurance' (standard deviation 1.0) at 5.5. 'Board capacity' recorded the lowest mean score of 5.0 , with a standard deviation of 0.9 .

As explained under the public entities section, Parasuraman et al. (1994: 202) recommend that service be assessed by subtracting the desired service level from the experienced service level. This should be done not only for each item but also for each dimension and for the overall instrument, with the answer called the measure of service superiority (MSS). In items and dimensions where this measure gives a positive answer the experienced service level exceeds the desired service level. In items and dimensions where this measure gives a negative answer the experienced service level is lower than the desired service level.

The calculated MSS for the overall assessment resulted in a mean service level of -0.8 (standard deviation 0.8 ). This implies that the mean experienced service fell short of the expected service by 0.8 when measured on a seven-point scale. Without exception the service level in all items fell short of the desired expectation when the MSS was used. The three items with the same least negative score of -0.4 were 'displaying impeccable integrity and honesty' (standard deviation 1.0), 'having members with expert financial knowledge' (standard deviation 1.1) and 'having the optimal ratio executives/non-executives' (standard deviation of 1.4). The item 'providing diversity through biographical composition' recorded the most negative score, namely -1.2 , with a standard deviation of 1.6. Regarding dimensionality, without exception the service level in all four dimensions fell short of the desired expectation when the MSS was used. The two dimensions with the same least negative score of -0.7 were 'directing and monitoring' and 'responsiveness and reliability', both with standard deviations of 0.9 . The dimension 'board capacity' recorded a score of -0.8 and 'assurance' a score of -0.9 , again both with a standard deviation of 0.9 .

Parasuraman et al. (1994: 202) recommend that service further be assessed by subtracting the lowest acceptable service level from the experienced service level. This should be done not only for each item but also for each dimension and for the overall instrument, with the answer called the measure of service adequacy (MSA). In items and dimensions where this measure gives a positive answer the experienced service level exceeds the lowest acceptable service level. In items and dimensions where this measure gives a negative answer the ex- perienced service level is lower than the lowest acceptable service level.

The calculated MSA for the overall assessment resulted in a mean service level of +0.5 (standard deviation 0.9 ). This implies that the mean experienced service exceeded the lowes acceptable service by 0.5 when measured on a seven-poin scale. Without exception, when measured against this lowered standard, the service level in all items exceeded the lowest acceptable expectation when the MSA was used. The two items that had the most positive mean score were 'avoiding conflict with personal interests' (mean score +1.3 and standard deviation 1.4) and 'providing adequate networking' (mean score +1.1 and standard deviation 1.6). Three items recorded the same least positive score of +0.1 (all with standard deviations 1.4 or 1.5), namely 'disallowing each other private, hidden agendas', 'being always properly prepared for meetings' and 'doing their homework thoroughly'. Three djmensions recorded the same positive mean score of +0.5 , with 'directing and monitoring' having a standard deviation of 1.0, 'board capacity' having a standard deviation of 1.1 and 'assurance' having a standard deviation of 1.2. The dimension with the highest positive score was 'responsiveness and reliability', with a mean score of +0.6 and a standard deviation of 1.0

\section{Comparison of the zones of tolerance and actual service in the two sectors}

Parasuraman et al. (1994: 202) report that a desired service level and an adequate service level are separated by a zone of tolerance. This area represents the range of service performance that is regarded as acceptable. In Parasuraman et al.'s (1994: 216) assessment of the service levels of four companies, the width of the zones of tolerance in the dimensions are just over one on a nine-point scale. The respondents' overall mean tolerance was 1.05 for the public entities and 1.27 for the listed industrial companies. The zones of tolerance in the four dimensions are indicated in Table 1 .

Judging by the zones of tolerance reported by Parasuraman et al. (1994: 216, Figure 1), that is approximately one on a nine-point scale in respect of the life insurance company, the South African respondents were at least as toierant as those in the United States. The poor MSA scores reported for the nonexecutive directors in public entities are therefore not a result of intolerance on the part of the South African respondents. The actual service is the point in issue. A graphical summary of these findings is given in Figure 1.

As can be seen from Figure 1, the corporate governance service of the public entity non-executive directors was in all dimensions at a level below the zone of tolerance. The service

Table 1 Zones of tolerance in the four dimensions

\begin{tabular}{lcc}
\hline Dimension & \multicolumn{2}{c}{ Mean zone of tolerance } \\
\hline Directing and monitoring & 10 & Pisted companies \\
Board capacity & 0.8 & 1.3 \\
Assurance & 1.1 & 1.3 \\
Responsiveness & 13 & 1.4 \\
\hline
\end{tabular}




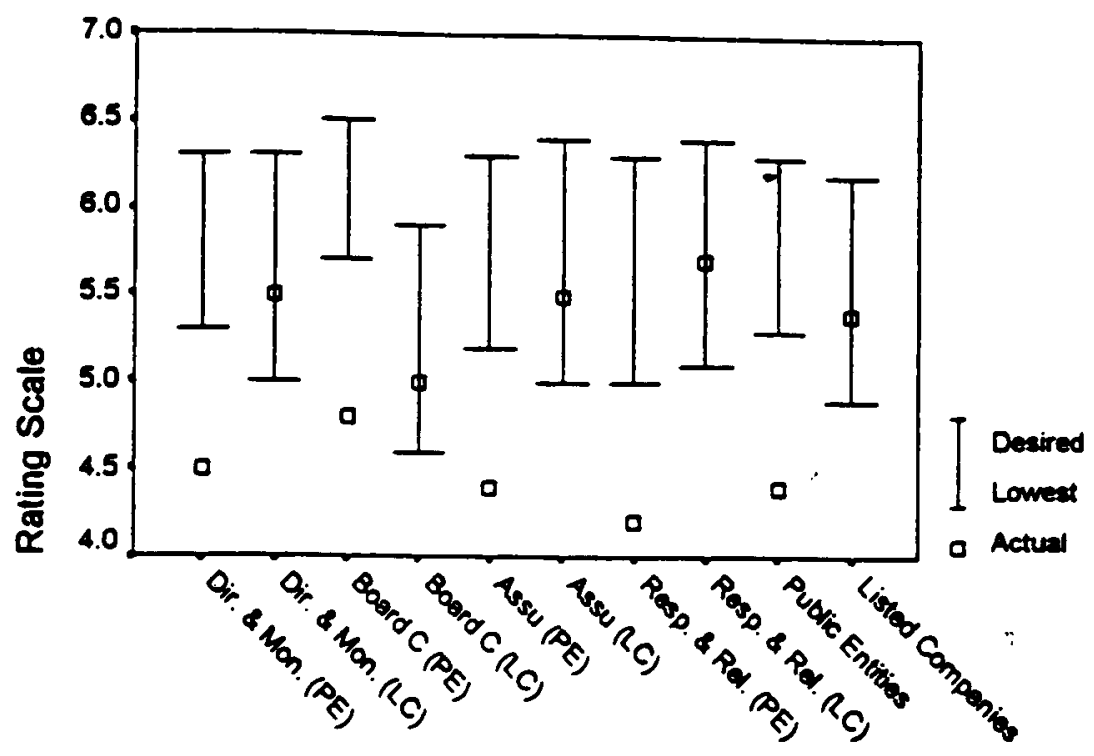

Dimensions

Figure 1 Zone of tolerance and rating

of the directors in the listed industrial companies was in all dimensions inside the zone of tolerance.

\section{International comparison}

Service quality can probably best be assessed if the results are compared with the results of similar studies of service quality in other service industries. Churchill (1979: 72) sees this as the final step in developing a valid instrument. In order to further analyze the results of these assessments of corporate governance service, the results were compared with the results of assessments of service where SERVQUAL was used. The comparisons were done on two levels, namely the measure of service superiority and the measure of service adequacy.

Two sets of published assessments of service at the MSS level where SERVQUAL was used, were compared with the assessment of corporate governance service at the MSS level in public entities and in listed industrial companies. Parasuraman et al. (1993: 147), read alongside Parasuraman et al. (1991: 446), produced an MSS assessment of an insurance company on a seven-point scale. This assessment is compared in Table 2 with the assessment of corporate governance service.

Although the dimensions were not the same, the insurance company managed to give superior service in one of the dimensions. The worst assessment of the insurance company, namely -1.6 , was the same as the best assessment received by the public entity non-executive directors. The worst assessment received by the public entity directors $(-2.1)$ was substantially worse than that received by the insurance company (-1.6). The listed company directors, on the other hand, although still recording negative findings at this high expected service level, outperformed the insurance and public entity sectors - the latter by far.

Herbert (1994: 17) reports library service findings using SERVQUAL as an instrument. Herbert's results and the cornorate governance findings are compared in Table 3.
In their best dimension the library service was superior by 1.2 while public entity non-executive directors fell short by 1.6 on theirs. Public entity non-executive directors also did substantially worse in their best dimension than the library service providers in their worst dimension. Listed company directors recorded a far better service than the public entity non-executive directors but still did not render any superior service.

This shows conclusively that, using MSS as a yardstick. public entity non-executive directors did not deliver any superior service in the measured dimensions. When compared with similar studies, other service providers rendered superior service in one of the measured dimensions. The public entity non-executive directors' service was rated substantially worse than other comparable services that had been reported on. The listed company directors also did not render any superior service on any of the dimensions but their service was nevertheless substantially better than that of the public entity directors.

Parasuraman et al. (1994: 217) report the service assessments of four companies at the MSA level. As these assessments were done on a nine-point scale, a comparison with the corporate governance service (done on a seven-point scale)

Table 2 Assessment of corporate governance service

\begin{tabular}{lccc}
\hline Dimension & Insurance & \multicolumn{1}{c}{ Corporate governance } \\
\hline Tangibles & & Public entities Listed companies \\
Assurance & 0.0 & - & - \\
Empathy & -1.0 & -1.9 & -0.9 \\
Responsiveness & -1.1 & - & - \\
Reliability & -1.3 & - & - \\
Responsiveness and reliability & - & - & - \\
Board capacity & -1.6 & -2.1 & -0.7 \\
Directing and monitoring & - & -1.6 & -0.8 \\
\hline
\end{tabular}


Table 3 Comparison of Herbert's results and the corporate governance findings

\begin{tabular}{lccc}
\hline Dimension & Library & \multicolumn{2}{c}{ Corporate governance } \\
\hline Tangibles & & Public entities Listed companies \\
Assurance & +1.2 & - & - \\
Empathy & -0.57 & -1.9 & -0.9 \\
Responsiveness & -0.68 & - & - \\
Reliability & -0.77 & - & - \\
Responsiveness and reliability & - & - & - \\
Directing and monitoring & - & -2.1 & -0.7 \\
Board capacity & - & -1.8 & -0.7 \\
\hline
\end{tabular}

Table 4 Comparisons with the corporate governance service

\begin{tabular}{lcccccc}
\hline Dimension & IT CO & Retail & Auto & Insurer & \multicolumn{2}{c}{ Corporate governance } \\
\hline Tangibles & & & & & $\begin{array}{c}\text { Public } \\
\text { entities }\end{array}$ & $\begin{array}{c}\text { Listed } \\
\text { companies }\end{array}$ \\
Assurance & +1.5 & +0.6 & +0.8 & +0.5 & - & - \\
Responsiveness & +0.4 & -0.4 & +0.5 & +0.2 & - & - \\
Reliability & +0.3 & -0.5 & +0.3 & +0.2 & - & - \\
Responsiveness & - & - & - & - & -0.9 & +0.6 \\
and reliability & & & & & & \\
Empathy & +0.3 & -0.4 & +0.4 & +0.2 & - & - \\
$\begin{array}{l}\text { Directing and } \\
\text { monitoring }\end{array}$ & - & - & - & - & -0.8 & +0.5 \\
Board capacity & - & - & - & - & -0.8 & +0.5 \\
\hline
\end{tabular}

should favour the corporate govemance service. This comparison is shown in Table 4

At this lower level of service expectation the measure of service adequacy (MSA) level three of the four companies, as well as the listed entity directors, provided the service at least adequately in all the measured dimensions. The service of the company rated worst still outperformed the public entity nonexecutive directors' service as it was rated more than adequate in one dimension while in its worst-rated dimension it did better than the public entity non-executive directors in their best dimension. The non-executive directors' service in public entities was rated as unacceptable in all the measured dimensions by a substantial margin, while the listed company directors, service was rated as acceptable.

\section{References}

Babakus, E. \& Boller, G.W. 1992. An empirical assessment of the SERVQUAL scale, Journal of Business Research, 24: 253-268.

Butler, J. 1991. Corporate govemance - who needs it? Accountancy, 108 24-25.

Bryne, J.A. 1996. The best and worst boards, Business Week. 25 November: $62-68$,

Carman M.C. 1990. Consumer perceptions of service quality: an assessment of the SERVQUAL dimensions, Journal of Retailing, 66(1): 33 55.

Chaston, I. 1995. A typology for evaluating branch-level perceptions of customer management processes within the United Kingdom clearing banks. The Service Industries Journal, 15(3): 332-349.

Churchill, G.A. 1979. A paradigm for developing better measures of me keting constructs, Journal of Marketing Research, 16: 64-73.

Conner, C. 1995. Trends in corporate govenance. Canadian Business Re. view, Autumn: 18-20

Corrin, J. 1993. A blatant slur on executive directors' integrity, Sociev of Incorporated Accountants and Auditors, 111:81-82.

Cronin, J.J. Jr. \& Taylor, S.A. 1992. Measuring service quality: a re-ex. amination, Journal of Marketing, 56(3): 55-68

Cronin, J.J. Jr. \& Taylor, S.A. 1994. SERVPREF versus SERVQUAL: reconciling performance-based and performance-minus-expectation measurement of service quality. Journal of Marketing, 58(1): 125-131

Daily, C.M. \& Dalton. D.R. 1994. Corporate governance and the bankrupt firm: an empirical assessment. Strategic M/anagement Journal, is 643-654

Davis, R. 1993. Good corporate governance needs a helping hand, $A C$ countancy, Vol. 111: 58-59.

De Castro, S. 1998. Disclosure of corporate governance - how are we do ing?, Accountancy SA, June: 23-27

Financial Mail. 1997. Special survey: top companies, 27 June: 363-366.

Finkelstein, S. \& Boyd, B.K. 1998. How much does the CEO matter? The role of managerial discression in setting the CEO compensation, Academy of Management Journal. 41(2): 179-199

Herbert, F. 1994. Service quality: an unobstructive investigation of interlibrary loans in large public libraries in Canada, Library and Information Science Research, 16(1): 3-21.

Kettinger, W.J. \& Lee, C.C. 1994. Perceived service quality and user sal. isfaction with the information services function. American Institute For Decision Sciences, 25(5'6): 737-766.

Melville-Ross, T. 1996. Better behavior in the boardroom, Accountancy. 117: 54.

Millstein, I.M. 1997. Red herring over independent boards, The New Yor: Times, 6 April: 10-11

Parasuraman, A., Zeithaml, V.A. \& Berry. L.L. 1988. SERVQUAL: a multiple-item scale for measuring consumer perceptions of service quality, Journal of Retailing. 64(1): 12-40.

Parasuraman, A., Zeithaml, V.A. \& Berry, L.L. 1991. Refinement and reassessment of the SERVQUAL scale, Journal of Retailing, 67(4): 420 450.

Parasuraman, A., Zeithaml, V.A. \& Berry, L.L. 1993. Research note more on improving service quality measurement, Journal of Retailing, 69(1): 140-147.

Parasuraman, A., Zeithaml, V.A. \& Berry. L.L. 1994. Altemative scales for measuring service quality: a comparative assessment based on psychometric and diagnostic criteria, Journal of Retailing, 70(3): 201230.

Parasuraman, A., Zeithaml, V.A. \& Berry, L.L. 1994. Reassessment of expectations as a comparison standard in measuring service quality: implications for further research. Journal of Marketing, 58: 111-124.

Pearce, J.A. \& Zahra, S.A. 1991. The relative power of CEOs and boants of directors: associations with corporate performance, Strategic Management Journal, 12: 135-153.

Pitt, L.F., Watson, R.T. \& Kavan. C.B. 1995. Service quality: a measure of information systems effectiveness. MIS Quarterly, 19: 173-187.

SAICA Editor. 1995. Reporting by Public Entities Act, 1992. Tech Talk. 12: 1-2.

Sanders, W.G. \& Carpenter, M.A. 1998. Internationalization and Firm governance: the roles of ceo compensation. top team compensation and board structure, Academy of . Lanagement Journal, 41(2): 158-178.

Singleton-Green, B. 1993. What the researchers found. Accountancy, 112: 45 .

Teas, R.K. 1994. Expectations as a comparison standard in measuring service quality: an assessment of a reassessment, Journal of Marketing. 58: $132-139$

Van Wyk, M.F. 1998. Service quality measurement for non-executive di rectors in public entities. Ph $D$ thesis. Johamnesburg: Rand Afrikaans University. $173 p$

White, M.D. \& Abels, E.G. 1995. Measuring service quality in special li braries: lessons from service marketing. Special Libraries, 86(1): 3645 


\section{Annexure 1}

\begin{tabular}{|c|c|c|c|c|}
\hline $\begin{array}{l}\text { Answers will be treated as } \\
\text { confidential and will be used for } \\
\text { statistical purposes only } \\
\text { Please indicate your perception of } \\
\text { the board's service regarding: }\end{array}$ & $\begin{array}{l}\text { My desired service } \\
\text { level } \\
\text { Low High } \\
\text { Please encircle }\end{array}$ & $\begin{array}{l}\text { My lowest } \\
\text { acceptable service } \\
\text { Low level } \\
\text { Please encircle }\end{array}$ & $\begin{array}{l}\text { Low High } \\
\text { Please encircle }\end{array}$ & Onfle \\
\hline $\begin{array}{l}\text { 1. Being independent (e.g. not ex- } \\
\text { employees, suppliers) }\end{array}$ & $123+567$ & $123+567$ & $123+567$ & 0406 \\
\hline $\begin{array}{l}\text { 2. Dependability in handling } \\
\text { shareholders' problems }\end{array}$ & 1234567 & $123+567$ & $123+567$ & $07-09$ \\
\hline $\begin{array}{l}\text { 3. Knowing the problems of the } \\
\text { industry }\end{array}$ & $123+567$ & $123+567$ & $123+567$ & 1012 \\
\hline $\begin{array}{l}\text { 4. Providing the governance } \\
\text { service at the right time }\end{array}$ & $123+567$ & $123+567$ & $123+567$ & $13-15$ \\
\hline $\begin{array}{ll}\text { 5. } & \text { Providing insight through } \\
\text { background (e. g. industry) }\end{array}$ & $123+567$ & $123+567$ & $123+567$ & 1618 \\
\hline $\begin{array}{l}\text { 6. Informing shareholders about } \\
\text { their governance }\end{array}$ & $123+567$ & 1234567 & $123+567$ & $19-21$ \\
\hline $\begin{array}{l}\text { 7. Promptness in taking } \\
\text { governance actions }\end{array}$ & $123+567$ & $123+567$ & $123+567$ & $22-24$ \\
\hline $\begin{array}{lll}\text { 8. Willingness to help } \\
\text { shareholders }\end{array}$ & 1234567 & 1234567 & $123+567$ & 2527 \\
\hline $\begin{array}{l}\text { 9. Readiness to respond to } \\
\text { shareholders' requests }\end{array}$ & $123+567$ & 1234567 & $123+567$ & 28,30 \\
\hline $\begin{array}{l}\text { 10. Having the confidence of } \\
\text { shareholders }\end{array}$ & $123+567$ & $123+567$ & $123+567$ & $31-33$ \\
\hline $\begin{array}{l}\text { 11. Making shareholders feel safe } \\
\text { with their governance }\end{array}$ & $123+567$ & $123+567$ & $123+567$ & $3+36$ \\
\hline $\begin{array}{l}\text { 12. Preventing the CEO from } \\
\text { misleading the board }\end{array}$ & 1234567 & $123+567$ & $123+567$ & 3739 \\
\hline $\begin{array}{l}\text { 13. Having the knowledge to } \\
\text { govern optimally }\end{array}$ & $123+567$ & 1234567 & $123+567$ & $40+42$ \\
\hline $\begin{array}{l}\text { 14. Providing commitment through } \\
\text { equity participation }\end{array}$ & $123+567$ & $123+567$ & $123+567$ & 13.13 \\
\hline $\begin{array}{l}\text { 15. Independence from executuves } \\
\text { for information }\end{array}$ & $123+567$ & $123+567$ & $123+567$ & $46+1$ \\
\hline $\begin{array}{l}\text { 16. Being truly a shareholder } \\
\text { appointment }\end{array}$ & $123+567$ & 1234567 & $123+567$ & 4953 \\
\hline $\begin{array}{l}\text { 17. Understanding what is } \\
\text { expected trom governors }\end{array}$ & 1234567 & $123+567$ & $123+567$ & 384 \\
\hline $\begin{array}{l}\text { 18. Governing continually and not } \\
\text { only when convenient }\end{array}$ & $123+567$ & $123+567$ & $123+567$ & 55.57 \\
\hline $\begin{array}{l}\text { 19. Delivering tangible benelits } \\
\text { knowing important people }\end{array}$ & $123+567$ & 1234567 & $123+567$ & $58-64$ \\
\hline
\end{tabular}




\section{Annexure 1 (cont.)}

\begin{tabular}{|c|c|c|c|c|}
\hline $\begin{array}{l}\text { Answers will be treated as } \\
\text { confidential and will be used for } \\
\text { statistical purposes only } \\
\text { Please indicate vour perception of } \\
\text { the board s senice regarding: }\end{array}$ & $\begin{array}{l}\text { My desired service } \\
\text { level } \\
\text { Low High } \\
\text { Please encircle }\end{array}$ & $\begin{array}{l}\text { My lowest } \\
\text { acceptable service } \\
\text { level High } \\
\text { Low Please encircle }\end{array}$ & $\begin{array}{l}\text { Board's actual } \\
\text { service level } \\
\text { Low High } \\
\text { Please encircle }\end{array}$ & Onees \\
\hline $\begin{array}{l}\text { 20. Being punctual and time } \\
\text { disciplined }\end{array}$ & $123+567$ & 1234567 & $123+567$ & 680 \\
\hline 21 Providing adequate networking & $123+567$ & $123+567$ & $123+567$ & $6+66$ \\
\hline $\begin{array}{l}\text { 22. Disallowing each other private, } \\
\text { conflicting agendas }\end{array}$ & $123+567$ & 1234567 & $123+56 ?$ & 6789 \\
\hline $\begin{array}{l}\text { 23. Being balanced in com- position } \\
\text { (e.g. tinancial, legal) }\end{array}$ & $123+567$ & $123+567$ & $123+567$ & 6072 \\
\hline $\begin{array}{l}\text { 24. Being assertive (not rubber } \\
\text { stamps) with the CEO }\end{array}$ & $123+567$ & $123+567$ & $123+567$ & $737 \%$ \\
\hline $\begin{array}{l}\text { 25. Anending to the important and } \\
\text { not to the sensational }\end{array}$ & $123+567$ & $123+567$ & $123+567$ & 787 \\
\hline $\begin{array}{l}\text { 26. Providing overall direction to } \\
\text { the CEO }\end{array}$ & $123+567$ & $123+567$ & $123+567$ & $0+106$ \\
\hline $27 \quad$ Properly monitoring the CEO & $123+567$ & $123+567$ & $123+567$ & $0780 \%$ \\
\hline $\begin{array}{l}28 \text { Being consistent in their } \\
\text { judgement }\end{array}$ & $123+567$ & $123+567$ & 1234567 & 1012 \\
\hline $\begin{array}{l}\text { 29. Issuing etror-free unbiased } \\
\text { tinancial statements }\end{array}$ & $123+567$ & $123+567$ & $123+567$ & $13+15$ \\
\hline $\begin{array}{l}\text { 30. Adding value through their } \\
\text { straiegic guidance }\end{array}$ & 1234567 & $123+567$ & $123+567$ & 1018 \\
\hline $\begin{array}{l}\text { 31. Utulising the best extemal } \\
\text { advice, and assistance }\end{array}$ & $123+567$ & $123+567$ & $123+567$ & $19 \% 21$ \\
\hline $\begin{array}{l}\text { 32. Goveming as if they per-sonally } \\
\text { financed the entity }\end{array}$ & 1234567 & $123+567$ & $123+567$ & 2724 \\
\hline $\begin{array}{l}\text { 33. Displaying impeccable in- tegrity } \\
\text { \& honesty eg own claims }\end{array}$ & $123+567$ & $123+567$ & $123+567$ & 2521 \\
\hline $\begin{array}{l}\text { 34. Having members with expert } \\
\text { financial knowledge }\end{array}$ & $123+567$ & $123+567$ & $123+567$ & 2838 \\
\hline $\begin{array}{l}\text { 35. Evaluatung and publicly reporting } \\
\text { their own performance }\end{array}$ & $123+567$ & $123+567$ & $123+567$ & 81133 \\
\hline $\begin{array}{l}\text { 36. Ensuring that sound financial } \\
\text { controls are in place }\end{array}$ & $123+567$ & $123+567$ & $123+567$ & 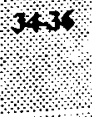 \\
\hline $\begin{array}{l}\text { 37. Being always properly } \\
\text { prepared for meetings }\end{array}$ & $123+567$ & $123+567$ & 1234567 & 379 \\
\hline $\begin{array}{l}\text { 38. Knowing the entity's objectives } \\
\text { and strategies }\end{array}$ & $123+567$ & $123+567$ & $123+567$ & $40,+2$ \\
\hline
\end{tabular}




\section{Annexure 1 (cont.)}

\begin{tabular}{|c|c|c|c|c|}
\hline $\begin{array}{l}\text { Answers will be treated as } \\
\text { confidential and will be used for } \\
\text { statistical purposes only } \\
\text { Please indicate your perception of } \\
\text { the board's service regarding: }\end{array}$ & $\begin{array}{l}\text { My desired service } \\
\text { level } \\
\text { Low High } \\
\text { Please encircle }\end{array}$ & $\begin{array}{l}\text { My lowest } \\
\text { acceptable service } \\
\text { level High } \\
\text { Low Please encircle }\end{array}$ & $\begin{array}{l}\text { Low High } \\
\text { Please encircle }\end{array}$ & onies: \\
\hline $\begin{array}{l}\text { 39. Knowing what info is needed to } \\
\text { govern and getting it }\end{array}$ & $123+567$ & $123+567$ & 1234567 & 4345 \\
\hline $\begin{array}{l}\text { 40. Ensuring organisational } \\
\text { objectives are met }\end{array}$ & $123+567$ & $123+567$ & $123+567$ & 16.18 \\
\hline $\begin{array}{l}\text { 41. Taking politically unpopular } \\
\text { action when needed }\end{array}$ & $123+567$ & $123+567$ & $123+567$ & 40.51 \\
\hline $\begin{array}{l}\text { 42. Taking their accountability } \\
\text { seriously }\end{array}$ & 1234567 & $123+567$ & $123+567$ & $\$ 254$ \\
\hline $\begin{array}{l}\text { 43. Refraining from acting as if } \\
\text { they were the executive }\end{array}$ & 1234567 & $123+567$ & $123+567$ & 5857 \\
\hline $\begin{array}{l}\text { 44. Attending all board and } \\
\text { committee meetings }\end{array}$ & 1234567 & $123+567$ & $123+567$ & 5860 \\
\hline $\begin{array}{l}\text { Meeting with optimum } \\
\text { regularity }\end{array}$ & $123+567$ & $123+567$ & $123+567$ & $6+67$ \\
\hline $\begin{array}{l}\text { 46. Asking appropriate, intelligent } \\
\text { questions }\end{array}$ & $123+567$ & $123+567$ & $123+567$ & 6466 \\
\hline $\begin{array}{l}\text { 47. Being optimally alert during } \\
\text { meetings }\end{array}$ & $123+567$ & $123+567$ & 1234567 & 6708 \\
\hline $\begin{array}{l}\text { 48. Neutralising dominating } \\
\text { persons during meetings }\end{array}$ & $123+567$ & $123+567$ & 1234567 & 7072 \\
\hline $\begin{array}{l}\text { 49. Doing their homework } \\
\text { thoroughly }\end{array}$ & 1234567 & 1234567 & 1234567 & 7375 \\
\hline $\begin{array}{l}\text { 50. Obtaining inputs trom reserved } \\
\text { people }\end{array}$ & 1234567 & $123+567$ & 1234567 & 7078 \\
\hline $\begin{array}{l}\text { 5l. Knowing the problems of the } \\
\text { industry }\end{array}$ & 1234567 & $123+567$ & $123+567$ & 0406 \\
\hline $\begin{array}{l}\text { 52. Avoiding conflict with personal } \\
\text { interests }\end{array}$ & $123+567$ & $123+567$ & $123+567$ & 0709 \\
\hline $\begin{array}{l}\text { 53. Displaying care and skill as } \\
\text { with their own affairs }\end{array}$ & $123+567$ & $123+567$ & $123+567$ & 1012 \\
\hline 54. Measuring the entity's output & $123+567$ & $123+567$ & $123+567$ & 13.15 \\
\hline $\begin{array}{l}\text { 55. Preventing the } \mathrm{CEO} \text { from } \\
\text { misleading the board }\end{array}$ & 1234567 & $123+567$ & $123+567$ & $16+18$ \\
\hline
\end{tabular}




\section{Annexure 2}

\begin{tabular}{|c|c|c|c|c|}
\hline $\begin{array}{l}\text { Answers will be treated as } \\
\text { confidential and will be used for } \\
\text { statistical purposes only } \\
\text { Please indicate your perception of } \\
\text { the board's senice regarding: }\end{array}$ & $\begin{array}{l}\text { My desired service } \\
\text { level } \\
\text { Low High } \\
\text { Please encircle }\end{array}$ & $\begin{array}{l}\text { My lowest } \\
\text { acceptable service } \\
\text { level } \\
\text { Low High } \\
\text { Please encircle }\end{array}$ & $\begin{array}{l}\text { Low High } \\
\text { Please encircle }\end{array}$ & Onin. \\
\hline $\begin{array}{l}\text { 1. Providing the govemance as } \\
\text { expected }\end{array}$ & $123+567$ & $123+567$ & 1234567 & $0 \% \%$ \\
\hline $\begin{array}{l}\text { 2. Dependability in handling } \\
\text { stakeholders problems }\end{array}$ & $123+567$ & $123+567$ & $123+567$ & $076 \%$ \\
\hline $\begin{array}{l}\text { 3. Performing the governance } \\
\text { right the first time }\end{array}$ & $123+567$ & $123+567$ & $123+567$ & 1012 \\
\hline $\begin{array}{l}\text { 4. Providing the governance } \\
\text { service at the right time }\end{array}$ & $123+567$ & $123+567$ & $123+567$ & $1+15$ \% \\
\hline $\begin{array}{l}\text { 5. Maintaining good records } \\
\text { about their governance }\end{array}$ & $123+567$ & $123+567$ & $123+567$ & 1018 \\
\hline $\begin{array}{l}\text { 6. Informing stakeholders about } \\
\text { their governance }\end{array}$ & $123+567$ & $123+567$ & $123+567$ & $19.21 \%$ \\
\hline $\begin{array}{l}\text { 7. Promplness in taking } \\
\text { governance actions }\end{array}$ & $123+567$ & $123+567$ & $123+567$ & $22-21 \%$ \\
\hline $\begin{array}{lll}\text { Willingness to help } \\
\text { shareholders }\end{array}$ & $123+567$ & $123+567$ & $123+567$ & $25 \% ?$ \\
\hline $\begin{array}{l}\text { 9. Readiness to respond to } \\
\text { stakeholders' requests }\end{array}$ & $123+567$ & $123+567$ & $123+567$ & 18.30 \\
\hline $\begin{array}{l}\text { 10. Having the confidence of } \\
\text { stakeholders }\end{array}$ & $123+567$ & $123+567$ & $123+567$ & 3173 \\
\hline $\begin{array}{l}\text { 11. Making stakeholders feel sate } \\
\text { with their governance }\end{array}$ & $123+567$ & $123+567$ & $123+567$ & $3+36$ \\
\hline $\begin{array}{l}\text { 12. Being courteous towards } \\
\text { stakeholders }\end{array}$ & $123+567$ & $123+567$ & $123+567$ & $373 \%$ \\
\hline $\begin{array}{l}\text { 13. Having the knowledge to } \\
\text { govern optimally }\end{array}$ & $123+567$ & $123+567$ & $123+567$ & $40+1$ \\
\hline $\begin{array}{l}\text { 14. Giving individual attention to } \\
\text { different stakeholders }\end{array}$ & $123+567$ & $123+567$ & $123+567$ & 10.13 \\
\hline $\begin{array}{ll}\text { 15. } & \begin{array}{l}\text { Caring adequately for } \\
\text { stakeholders }\end{array} \\
\end{array}$ & $123+567$ & $123+567$ & $123+567$ & $46+1 \%$ \\
\hline $\begin{array}{l}\text { 16. Having the stakeholders' best } \\
\text { interests at heart }\end{array}$ & $123+567$ & $123+567$ & $123+567$ & 495 \\
\hline $\begin{array}{l}\text { 17. Understanding what is } \\
\text { expected from governors }\end{array}$ & $123+567$ & $123+567$ & $123+567$ & 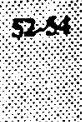 \\
\hline $\begin{array}{l}\text { 18. Governing continually and not } \\
\text { only when convenient }\end{array}$ & $123+567$ & $123+567$ & $123+567$ & 55.57 \\
\hline $\begin{array}{l}\text { 19. Delivening tangible benefits by } \\
\text { knowing important people }\end{array}$ & $123+567$ & $123+567$ & $123+567$ & 5869 \\
\hline
\end{tabular}




\section{Annexure 2 (cont.)}

\begin{tabular}{|c|c|c|c|c|}
\hline $\begin{array}{l}\text { Answers will be treated as } \\
\text { confidential and will be used for } \\
\text { statistical purposes only } \\
\text { Please indicate your perception of } \\
\text { the board's service regarding: }\end{array}$ & $\begin{array}{l}\text { My desired service } \\
\text { level } \\
\text { Low High } \\
\text { Please encircle }\end{array}$ & $\begin{array}{l}\text { My lowest } \\
\text { acceptable service } \\
\text { level } \\
\text { Low High } \\
\text { Please encircle }\end{array}$ & $\begin{array}{l}\text { Low High } \\
\text { Please encircle }\end{array}$ & offee \\
\hline $\begin{array}{l}\text { 20. Controlling } \\
\text { remuneration }\end{array}$ & $123+567$ & $123+567$ & $123+567$ & 61.63 \\
\hline 21. Providing adequate networking & $123+567$ & 1234567 & $123+567$ & $6+66$ \\
\hline $\begin{array}{l}\text { 22. Disallowing each other private, } \\
\text { conflicting agendas }\end{array}$ & $123+567$ & $123+567$ & 1234567 & 67.69 \\
\hline $\begin{array}{l}\text { 23. Being balanced in com- position } \\
\text { e.g. tinancial, legal }\end{array}$ & $123+567$ & $123+567$ & $123+567$ & 70.72 \\
\hline $\begin{array}{l}\text { 24. Being assertive (not rubber } \\
\text { stamps) with the CEO }\end{array}$ & $123+567$ & $123+567$ & $123+567$ & $73-75$ \\
\hline $\begin{array}{l}\text { 25. Attending to the important and } \\
\text { not to the sensational }\end{array}$ & $123+567$ & $123+567$ & $123+567$ & $26-78$ \\
\hline $\begin{array}{l}\text { 26. Providing overall direction to } \\
\text { the CEO }\end{array}$ & $123+567$ & 1234567 & 1234567 & $0+106$ \\
\hline 27. Properly monitoring the CEO & $123+567$ & $123+567$ & $123+567$ & 0709 \\
\hline 28. Controlling director nomination & $123+567$ & 1234567 & $123+567$ & 10,12 \\
\hline $\begin{array}{l}\text { 29. Being led by a non-executive } \\
\text { chairperson }\end{array}$ & $123+567$ & $123+567$ & $123+567$ & 13,15 \\
\hline $\begin{array}{l}\text { 30. Adding value through their } \\
\text { strategic guidance }\end{array}$ & $123+567$ & $123+567$ & $123+567$ & 1618 \\
\hline $\begin{array}{l}\text { 31. Utilising the best external } \\
\text { advice and assistance }\end{array}$ & $123+567$ & $123+567$ & 1234567 & $19+21$ \\
\hline $\begin{array}{l}\text { 32. Serving on the board for an } \\
\text { optimal period only }\end{array}$ & $123+567$ & 1234567 & 1234567 & 22,24 \\
\hline $\begin{array}{l}\text { 33. Displaying impeccable integ- } \\
\text { rity, honesty eg own claims }\end{array}$ & $123+567$ & $123+567$ & 1234567 & $1+4$ \\
\hline $\begin{array}{l}\text { 34. Having members with expert } \\
\text { financial knowledge }\end{array}$ & $123+567$ & $123+567$ & $123+567$ & 28,31 \\
\hline $\begin{array}{l}\text { 35. Evaluating \& publicly repor-ting } \\
\text { their own performance }\end{array}$ & $123+567$ & 1234567 & 1234567 & 3.33 \\
\hline $\begin{array}{l}\text { 36. Ensuring that sound tinancial } \\
\text { controls are in place }\end{array}$ & $123+567$ & 1234567 & $123+567$ & $3+36$ \\
\hline $\begin{array}{l}\text { 37. Being always properly } \\
\text { prepared for meetings }\end{array}$ & $123+567$ & $123+567$ & $123+567$ & $37-39$ \\
\hline $\begin{array}{l}\text { 38. Knowing the entity's objectives } \\
\text { and strategies }\end{array}$ & $123+567$ & 1234567 & $123+567$ & $40+2$ \\
\hline
\end{tabular}




\section{Annexure 2 (cont.)}

\begin{tabular}{|c|c|c|c|c|}
\hline $\begin{array}{l}\text { Answers will be treated as } \\
\text { confidential and will be used for } \\
\text { statistical purposes only } \\
\text { Please indicate your perception of } \\
\text { the board's service regarding: }\end{array}$ & $\begin{array}{l}\text { My desired service } \\
\text { level } \\
\text { Low High } \\
\text { Please encircle }\end{array}$ & $\begin{array}{l}\text { My lowest } \\
\text { acceptable service } \\
\text { level High } \\
\text { Low encircle } \\
\text { Please en }\end{array}$ & $\begin{array}{l}\text { Board's actual } \\
\text { service level } \\
\text { Low High } \\
\text { Please encircle }\end{array}$ & 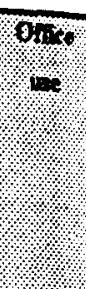 \\
\hline $\begin{array}{l}\text { 39. Knowing what info is needed to } \\
\text { govern \& getting it }\end{array}$ & $123+567$ & $123+567$ & 1234567 & 435 \\
\hline $\begin{array}{l}\text { 40. Ensuring organisational } \\
\text { objectives are met }\end{array}$ & $123+567$ & $123+567$ & $123+567$ & $18 \%$ \\
\hline $\begin{array}{l}\text { 41. Taking politically unpopular } \\
\text { action when needed }\end{array}$ & $123+567$ & $123+567$ & $123+567$ & 40.51 \\
\hline $\begin{array}{l}\text { 42. Taking their accountability } \\
\text { seriously }\end{array}$ & $123+567$ & $123+567$ & $123+567$ & 8281 \\
\hline $\begin{array}{l}\text { 43. Willingness to share business } \\
\text { risk }\end{array}$ & $123+567$ & $123+567$ & $123+567$ & 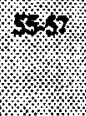 \\
\hline $\begin{array}{l}\text { 44. Attending all board and } \\
\text { committee meetings }\end{array}$ & $123+567$ & $123+567$ & $123+567$ & 8860 \\
\hline $\begin{array}{l}\text { 45. Meeting with optimum } \\
\text { regularity }\end{array}$ & $123+567$ & $123+567$ & $123+567$ & 616 \\
\hline $\begin{array}{l}\text { 46. Asking appropriate, intelligent } \\
\text { questions }\end{array}$ & $123+567$ & $123+567$ & $123+567$ & 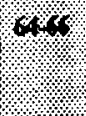 \\
\hline $\begin{array}{l}\text { 47. Being optimally alert during } \\
\text { meetings }\end{array}$ & $123+567$ & $123+567$ & $123+567$ & $6786 \%$ \\
\hline $\begin{array}{l}\text { 48. Neutralising dominating } \\
\text { persons during meetings }\end{array}$ & $123+567$ & $123+567$ & $123+567$ & $1071 \%$ \\
\hline $\begin{array}{l}\text { 49. Doing their homework } \\
\text { thoroughly }\end{array}$ & $123+567$ & $123+567$ & $123+567$ & 1358. \\
\hline $\begin{array}{l}\text { 50. Providing diversity through } \\
\text { biographical composition (e.g. } \\
\text { race, age, sex) }\end{array}$ & $123+567$ & $123+567$ & $123+567$ & $76 \%$ \\
\hline $\begin{array}{l}\text { 51. Avoiding conflict with personal } \\
\text { interests }\end{array}$ & $123+567$ & $123+567$ & $123+567$ & $040 \%$ \\
\hline $\begin{array}{l}\text { 52. Displaying care and skill as } \\
\text { with their own affairs }\end{array}$ & $123+567$ & $123+567$ & $123+567$ & 0769 \\
\hline $\begin{array}{l}\text { 53. Having an optimal ratio } \\
\text { executives / non-executives }\end{array}$ & $123+567$ & $123+567$ & $123+567$ & 1011. \\
\hline 54. Overall govemance quality & $123+567$ & $123+567$ & $123+567$ & $13+15$ \\
\hline $\begin{array}{l}\text { 55. Would you recommend the board } \\
\text { to another company? }\end{array}$ & Yes & May be & Yo & \\
\hline $\begin{array}{l}\text { 56. Have you ever seriously queried } \\
\text { their govemance? }\end{array}$ & Yes & & Vo & \\
\hline
\end{tabular}




\section{Annexure 3}

\section{PUBLIC ENTITIES}

MEASURE OF SERVICE SUPERIORITY: VARIABLE NUMBER ONE

\begin{tabular}{|c|c|c|c|c|}
\hline Individual scale & & vality & & \\
\hline dimensions & Top & Good & & Fair / Poor \\
\hline Directing \& monitoring & $-0.71^{2}$ & $-1,33^{*}$ & - & $2,49^{\circ}$ \\
\hline Board capacity & $-0.53^{2}$ & $-1,04^{2}$ & & $-2.42^{\circ}$ \\
\hline Assurance & $-0,68^{2}$ & $-1,31^{2}$ & $\cdot$ & $-3,08^{\circ}$ \\
\hline Responsiveness \& reliability & $-0.75^{\circ}$ & $-1,32^{2}$ & - & $2.53^{\circ}$ \\
\hline Combined scale & $-0,87^{2}$ & $-1,27^{\wedge}$ & - & $2,68^{\circ}$ \\
\hline
\end{tabular}

MEASURE OF SERVICE ADEQUACY: VARIABLE NUMBER ONE

\begin{tabular}{|llccc|}
\hline Individual scale & \multicolumn{3}{c}{ Overall quality } \\
dimensions & Top & Good & Fair /Poor \\
\cline { 3 - 5 } Directing \& monitoring & $0,68^{\circ}$ & $-0,24^{\circ}$ & $-1,55^{\circ}$ \\
Board capacity & $0,33^{\circ}$ & $-1,11^{\circ}$ & $-1,64^{\circ}$ \\
Assurance & $0,64^{\circ}$ & $0,03^{\circ}$ & $-1,83^{\circ}$ \\
Responsiveness \& reliability & $0,75^{\circ}$ & $-0,02^{\circ}$ & $1,54^{\circ}$ \\
Combined scale & $0,67^{\circ}$ & $-0,14^{\circ}$ & $-1,72^{\circ}$ \\
\hline
\end{tabular}

\section{LISTED COMPANIES}

MEASURE OF SERVICE SUPERIORITY: VARIABLE NUMBER ONE

\begin{tabular}{|c|c|c|c|c|}
\hline Individual scale & & Uality & & \\
\hline dimensions & Top & Good & & Fair / Poor \\
\hline Directing \& monitoring & $-0,71^{2}$ & $-1,33^{\prime}$ & - & $2.49^{\circ}$ \\
\hline Board capacity & $-0,53^{\star}$ & $-1.04^{\prime}$ & & $-2,42^{\circ}$ \\
\hline Assurance & $-0,58^{a}$ & -1.31 & & $-3.08^{\circ}$ \\
\hline Responsiveness \& reliability & $-0.75^{\prime}$ & $-1.32^{\prime \prime}$ & $\cdot$ & $2.53^{\circ}$ \\
\hline Combined scale & $-0,87^{\prime}$ & $-1.27^{a}$ & - & $2,68^{\circ}$ \\
\hline
\end{tabular}

MEASURE OF SERVICE ADEQUACY: VARIABLE NUMBER ONE

\begin{tabular}{|c|c|c|c|}
\hline \multirow{2}{*}{$\begin{array}{l}\text { Individual scale } \\
\text { dimensions }\end{array}$} & \multicolumn{3}{|c|}{ Overall quality } \\
\hline & Top & Good & Fair / Poor \\
\hline Directing \& monitoring & $0,68^{2}$ & $-0.24^{2}$ & $-1.55^{\circ}$ \\
\hline Board capacity & $0,33^{\circ}$ & $-1,11^{\circ}$ & $-1,64^{\circ}$ \\
\hline Assurance & $0,64^{2}$ & $0,03^{\circ}$ & $-1,83^{\circ}$ \\
\hline Responsiveness \& reliability & $0,75^{\circ}$ & $-.0,02^{\circ}$ & $1.54^{\circ}$ \\
\hline Combined scale & $0,67^{2}$ & $-0,14^{2}$ & $-1,72^{\circ}$ \\
\hline
\end{tabular}

Notes:

$\because=$ Means with the same superscripts are not significantly different for each dimension and means with different superscripts are significantly different for each dimension.

Significant differences in mean scale values of respondents ( $0=$ indifference) - segmented according to the overall quality variabie Number one 


\section{Annexure 4}

\section{PUBLIC ENTITIES}

MEASURE OF SERVICE SUPERIORITY: VARIABLES NUMBERS TWO AND THREE

\begin{tabular}{|lllll|}
\hline Individual scale & \multicolumn{2}{l}{ Recommend } & \multicolumn{2}{l}{ Problem } \\
\cline { 2 - 5 } dimensions & Yes & No & Yes & No \\
\hline Directing \& monitoring & $-1,13^{\circ}$ & $-2,57^{\circ}$ & $-2,12^{\circ}$ & $-1,57^{\circ}$ \\
Board capacity & $-0,97^{\circ}$ & $-2,36^{\circ}$ & $-2,38^{\circ}$ & $-1,07^{\circ}$ \\
Assurance & $-1,17^{\circ}$ & $-3,04^{\circ}$ & $-2,50^{\circ}$ & $-1,75^{\circ}$ \\
Responsiveness \& reliab & $-1.18^{\circ}$ & $-2,52^{\circ}$ & $-2,28^{\circ}$ & $-1,47^{\circ}$ \\
Combined scale & $-1,15^{\circ}$ & $-2,75^{\circ}$ & $-2,31^{\circ}$ & $-1,60^{\circ}$ \\
\hline
\end{tabular}

MEASURE OF SERVICE ADEQUACY: VARIABLES NUMBERS TWO AND THREE

\begin{tabular}{|c|c|c|c|c|}
\hline Individual scale & Recom & & Problen & \\
\hline dimensions & Yes & No & Yes & No \\
\hline Directing \& monitoring & $0,02^{4}$ & $-1,60^{\circ}$ & $-1,20^{\circ}$ & $-0,42^{\circ}$ \\
\hline Board capacity & $0,03^{2}$ & $-1.62^{\circ}$ & $-1,52^{b}$ & $-0,22^{\prime}$ \\
\hline Assurance & $0,26^{\circ}$ & $-1,84^{\circ}$ & $-1,13^{\circ}$ & $-0,51^{*}$ \\
\hline Responsiveness \& reliab & $0,22^{2}$ & $-1,54^{\circ}$ & $-1,14^{\circ}$ & $-0,14^{\circ}$ \\
\hline Combined scale & $0,09^{\circ}$ & $-1.80^{\circ}$ & $-1,20^{\circ}$ & $-0.47^{\circ}$ \\
\hline
\end{tabular}

\section{LISTED COMPANIES}

MEASURE OF SERVICE SUPERIORITY: VARIABLES NUMBERS TWO AND THREE

\begin{tabular}{|lllllll|}
\hline Individual scale & \multicolumn{2}{c}{ Recommend } & \multicolumn{2}{c}{ Queried } \\
\cline { 2 - 6 } dimensions & Yes & May be & No & Yes & No \\
\hline Directing \& monitoring & $-0,52^{\mathrm{a}}$ & $-0,88^{\circ}$ & $-2,53^{\circ}$ & $-0,62^{\circ}$ & $-1,13^{\circ}$ \\
Board capacity & $-0,65^{\circ}$ & $-0,75^{\circ}$ & $-2,64^{\circ}$ & $-0,66^{\circ}$ & $-1,55^{\circ}$ \\
Assurance & $-0,51^{\circ}$ & $-0,74^{\circ}$ & $-2,06^{\circ}$ & $-0,63^{\circ}$ & $-0,96^{\circ}$ \\
Responsiveness \& reliab & $-0,56^{\circ}$ & $-0,92^{\circ}$ & $-2,38^{\circ}$ & $-0,73^{\circ}$ & $-1,08^{2}$ \\
Combined scale & $-0,54^{\circ}$ & $-0,90^{\circ}$ & $-2,62^{\circ}$ & $-0,66^{\circ}$ & $-1,12^{\circ}$ \\
\hline
\end{tabular}

MEASURE OF SERVICE ADEQUACY: VARIABLES NUMBERS TWO AND THREE

\begin{tabular}{|c|c|c|c|c|c|}
\hline \multirow{2}{*}{$\begin{array}{l}\text { Individual scale } \\
\text { dimensions }\end{array}$} & \multicolumn{2}{|c|}{ Recommend } & \multicolumn{3}{|c|}{ Queried } \\
\hline & Yes & May be & No & Yes & No \\
\hline Directing \& monitoring & $0,71^{2}$ & $0,54^{\prime}$ & $-1.23^{\circ}$ & $0,72^{\circ}$ & $-0.13^{\circ}$ \\
\hline Board capacity & $0,77^{\wedge}$ & $0,6^{\prime}$ & $-1.67^{\circ}$ & $0,86^{\circ}$ & $-0,60^{\circ}$ \\
\hline Assurance & $0,81^{\bullet}$ & $0,64^{\prime}$ & $-0.81^{b}$ & $0.81^{\circ}$ & $-0,02^{\circ}$ \\
\hline Responsiveness \& reliab & $0,76^{*}$ & $0.52^{\circ}$ & $-1,63^{\circ}$ & $-0,67^{\prime}$ & $-0.16^{\circ}$ \\
\hline Combined scale & $0,72^{\prime}$ & $0.53^{\circ}$ & $-1,24^{b}$ & $0,71^{\circ}$ & $-0,07^{\circ}$ \\
\hline
\end{tabular}

Notes:

' $=$ Means with the same superscripts are not significantly different for each dimension and means with different superscripts are significantly different for each dimension.

Significant differences in mean scale values of respondents $(0=$ indifference) - segmented according to the overall quality variables Numbers two and three 


\section{Annexure 5}

\begin{tabular}{|c|c|c|c|c|c|c|c|c|c|c|}
\hline \multirow{3}{*}{$\begin{array}{l}\text { LISTED COMPANIES } \\
\text { Statement }\end{array}$} & \multicolumn{10}{|c|}{ Mean Scores (MS) and Standard Deviation (SD) } \\
\hline & \multicolumn{2}{|c|}{ Desired } & \multicolumn{2}{|c|}{$\begin{array}{l}\text { Lowest } \\
\text { acceptable }\end{array}$} & \multicolumn{2}{|c|}{ Actual } & \multicolumn{2}{|c|}{ MSS } & \multicolumn{2}{|c|}{ MSA } \\
\hline & MS & SD & MS & SD & MS & SD & MS & SD & MS & SO \\
\hline Directing \& monitoring - overall mean scores & 6,3 & 0,5 & 5,0 & 0,9 & 5,5 & 0,9 & $-0,7$ & 0,9 & 0,5 & 1,0 \\
\hline 18 Governing continually and not only when convenient & 6.4 & 0.8 & 5,2 & 1.2 & 5.7 & 1.2 & -0.7 & 1.2 & 0.5 & 1.3 \\
\hline 21 Providing adequate networking & 5.5 & 1.2 & 3,8 & 1.5 & 4.9 & 1.3 & -0.7 & 1.3 & 1,1 & 1,6 \\
\hline 23 Being balanced in composition - financial, legal & 6.1 & 0.9 & 4.6 & 1,2 & 5.2 & 1,2 & -0.9 & 1,3 & 0.7 & 1.5 \\
\hline 30 Adding value through their strategic guidance & 6.2 & 0.9 & 4.8 & 1,4 & 5.3 & 1,2 & .0 .9 & 1.3 & 0.5 & 1,6 \\
\hline 31 Utilising the best external advice and assistance & 6.1 & 0.8 & 4.7 & 1,2 & 5.5 & 1,3 & -0.7 & 1.3 & 0,8 & 1,3 \\
\hline 34 Having members with expert financial knowledge & 6.3 & 0,8 & 5,2 & 1,2 & 5.6 & 1,0 & -0.4 & 1.1 & 0.7 & 1,2 \\
\hline 36 Ensuring that sound financial controls are in place & 6.7 & 0.6 & 5,8 & 1.3 & 6.2 & 0,9 & $.0,5$ & 0.8 & 0.4 & 1.0 \\
\hline 37 Being always properly prepared for meetings & 6.6 & 0,6 & 5,6 & 1,2 & 5.7 & 1.0 & -09 & 1.0 & 0.1 & 1.5 \\
\hline 39 Knowing what info is needed to govern and getting it & 6,2 & 0,7 & 4,9 & 1.2 & 5.5 & 1,0 & -0.7 & 1.0 & 0.5 & 1.2 \\
\hline 40 Ensuring the organisational objectives are met & 6,3 & 0,8 & 5.1 & 1,3 & 5.6 & 1,0 & $-0,7$ & 1.0 & 0.6 & 1.2 \\
\hline 41 Taking politically unpopular action when needed & 6.2 & 0.9 & 5.1 & 1,3 & 5,4 & 1,3 & $-0,8$ & 1.1 & 0.4 & 1,3 \\
\hline 43 Willingness to share business risk & 5,8 & 1.0 & 4,4 & 1,3 & 5.2 & 1,1 & -0.5 & 1,2 & 0.8 & 1.2 \\
\hline 49 Doing their homework thoroughly & 6.4 & 0.8 & 5,4 & 1.2 & 5.5 & 1,3 & -1.0 & 1,3 & 0.1 & 1.4 \\
\hline 51 Avoiding conflict with personal interests & 6.6 & 0.7 & 5,6 & 1,3 & 5.7 & 1,3 & -0.9 & 1,1 & 1.3 & 1,4 \\
\hline 52 Displaying care and skill as with own affairs & 6.5 & 0.9 & 5.5 & 1,3 & 5.9 & 1,1 & -0.5 & 0,8 & 0.4 & 1,1 \\
\hline Board capacity & 5,9 & 0,7 & 4,6 & 1,0 & 5,0 & 0,9 & $.0,8$ & 1,0 & 0,5 & 1,1 \\
\hline 3 Knowing the problems of the industry & 6.6 & 0.7 & 5.1 & 1,2 & 5.8 & 1.1 & -0.8 & 1.0 & 0.8 & 1.3 \\
\hline 15 Independence from executives for information & 5.8 & 0,9 & 4.2 & 1.4 & 5.1 & 1.1 & -0.7 & 1.1 & 0.9 & 1,3 \\
\hline 16 Being truly a sharehoider appointment & 5.5 & 1,3 & 4,1 & 6.7 & 4.8 & 1,8 & -0.7 & 1,8 & 0.6 & 1,9 \\
\hline 22 Disallowing each other private conflicting agendas & 6.5 & 0,9 & 5.5 & 1.4 & 5.6 & 1.4 & .0 .9 & 1,4 & 0.1 & 1.4 \\
\hline 32 Serving on the board for an optimal period only & 5.1 & 1.4 & 3.7 & 1.5 & 4.2 & 1.5 & -0.9 & 1.5 & 0.5 & 1,8 \\
\hline 46 Asking appropriate intelligent questions & 6.3 & 0.8 & 5.3 & 1.3 & 5.5 & 1.3 & -0.8 & 1.2 & 0.2 & 1.3 \\
\hline 50 Providing diversity through biographical composition & 5,3 & 1.5 & 3.8 & 1,6 & 4.1 & 1.5 & $-1,2$ & 1.6 & 0.4 & 1,6 \\
\hline 53 Having the optimal ratio executives / non-executives & 5,8 & 1,3 & 4.7 & 1.5 & 5.4 & 1,3 & -0.4 & 1.4 & 0.7 & 1.3 \\
\hline Assurance & 6,4 & 0,5 & 5,0 & 0,9 & 5,5 & $\overline{1.0}$ & $.0,9$ & 0,9 & 0,5 & $\overline{1,2}$ \\
\hline 7 Promptness in taking governance action & 6.2 & 0.8 & 4,7 & 1,2 & 5.3 & 1.2 & -0.9 & 1.1 & 0.6 & 1.0 \\
\hline 11 Making shareholders feel safe with their governance & 6.4 & 0.7 & 4.9 & 1.2 & 5,6 & 1.2 & -0.8 & 1.0 & 0.7 & 1.3 \\
\hline 12 Preventing the $C E O$ from misleading the board & 6.8 & 0.4 & 5,9 & 1,0 & 6.2 & 1.2 & -0.7 & 1.2 & 0.3 & 1.4 \\
\hline 13 Having the knowledge to optimally govern & 6.4 & 0.7 & 5.0 & 1.0 & 5.5 & 1.1 & -0.9 & 1.0 & 0.6 & 1.3 \\
\hline 24 Being assertive (not rubber stamps) with the CEO & 6.4 & 0.8 & 4.9 & 1.2 & 5.5 & 1,3 & -0.9 & 1,4 & 0.5 & 1.6 \\
\hline 26 Providing overall direction to the CEO & 6,1 & 1,0 & 4,6 & 1,3 & 5.2 & 1.4 & .0 .9 & 1.3 & 0.6 & 1.6 \\
\hline 27 Properly monitoring the CEO & 6.2 & 0.8 & 4.9 & 1.4 & 5.3 & 1,3 & .0 .9 & 1.4 & 0.4 & 1.8 \\
\hline Responsiveness \& reliability & 6,4 & 0,6 & 5,1 & 1,0 & 5.7 & 1,0 & $-0,7$ & 0,9 & 0,6 & 1,0 \\
\hline 2 Dependability in handling stakeholders problems & 6.4 & 0.8 & 4.8 & 1.3 & 5.6 & 1.3 & -0.8 & 1.2 & 0.7 & 1.3 \\
\hline 4 Providing the governance service at the right time & 6.2 & 0.8 & 4.7 & 1,3 & 5.3 & 1.2 & -0.9 & 1,1 & 0.7 & 1.3 \\
\hline 8 Willingness to help stakeholders & 6,3 & 0.9 & 4.8 & 1.4 & 5.5 & 1,2 & -0.7 & 1,0 & 0.8 & 1,2 \\
\hline 9 Readiness to respond to stakeholders' requests & 6.2 & 0.8 & 4.9 & 1,4 & 5.6 & 1,3 & .0 .6 & 1.1 & 0.7 & 1,2 \\
\hline 10 Having the confidence of shareholders & 6.5 & 0.7 & 5.2 & 1,2 & 5.7 & 1,3 & -0.8 & 1,3 & 0.6 & 1,4 \\
\hline 33 Displaying impeccable integrity, honesty: own claims & 6.8 & 0.6 & 6.1 & 1.2 & 6.4 & 1.2 & -0.4 & 1,0 & 0.3 & 1,3 \\
\hline JSE-ECGSI overall mean scores & 6,2 & 0,5 & 4,9 & 0,8 & 5,4 & 0,9 & $.0,8$ & 0,8 & 0,5 & 0,9 \\
\hline & & & & & & & & & & \\
\hline
\end{tabular}




\section{Annexure 5 (cont.)}

\begin{tabular}{|c|c|c|c|c|c|c|c|c|c|c|}
\hline \multirow{3}{*}{$\begin{array}{l}\text { PUBLIC ENTITIES } \\
\text { Statement }\end{array}$} & \multicolumn{10}{|c|}{ Mean Scores (MS) and Standard Deviation (SD) } \\
\hline & \multicolumn{2}{|c|}{ Desired } & \multicolumn{2}{|c|}{$\begin{array}{l}\text { Lowest } \\
\text { acceptable }\end{array}$} & \multicolumn{2}{|c|}{$\begin{array}{l}\text { Actual } \\
\text { perceptio } \\
\text { n }\end{array}$} & \multicolumn{2}{|c|}{ MSS } & \multicolumn{2}{|c|}{ MSA } \\
\hline & MS & SD & MS & SD & MS & SD & MS & SD & MS & SD \\
\hline Directing \& monitoring - overall moan scores & 6,3 & 0,5 & 5,3 & 0,8 & 4,5 & 1,0 & $-1,8$ & 1,1 & $-0,8$ & 1,2 \\
\hline 24 Being assertive (not rubber stamps) with the CEO & 6.2 & 0.9 & 5,1 & 1,3 & 4.8 & 1.3 & $-1,4$ & 1,4 & $-0,3$ & 1,6 \\
\hline 36 Ensuring that sound financial controls are in place & 6.6 & 0.8 & 5.9 & 1.1 & 5.4 & 1,4 & $-1,1$ & 1.3 & $-0,4$ & 1,5 \\
\hline 46 Asking appropriate, intelligent questions & 6.2 & 0.8 & 5.2 & 1.1 & 4.5 & 1,3 & $-1,7$ & 1,4 & -0.7 & 1,7 \\
\hline 54 Measuring the entity's output & 6.3 & 0.7 & 5.3 & 1.9 & 4.7 & 1.3 & $-1,6$ & 1,4 & -0.7 & 1.4 \\
\hline 27 Properly monitoring the CEO & 6.1 & 0,8 & 5.1 & 1.1 & 4,4 & 1.3 & -1.7 & 1.4 & $-0,8$ & 1.5 \\
\hline 31 Utilsing the best external advice and assistance & 5.9 & 1.1 & 4.8 & 1,1 & 4.0 & 1.2 & -1.9 & 1.4 & $-0,8$ & 1,5 \\
\hline 40 Ensunng the organisational abjectives are met & 6.2 & 1.0 & 5.0 & 1.3 & 4.2 & 1.2 & $-2,0$ & 1.2 & $-0,8$ & 1.4 \\
\hline 53 Displaying care and skill as with their own affairs & 6.4 & 0.7 & 5,6 & 1.1 & 4.8 & 1.2 & -1.7 & 1.3 & $-0,8$ & 1,4 \\
\hline 55 Preventing the CEO from misleading the board & 6.6 & 0.7 & 5.8 & 0.9 & 5.0 & 1.5 & $-1,5$ & 1.5 & -0.8 & 1.7 \\
\hline 25 Providing overall direction to the CEO & 6.5 & 0.6 & 5.4 & 1.0 & 4.5 & 1.4 & $-2,0$ & 1,5 & -0.9 & 1.7 \\
\hline 39 Knowing what info is needed to govern and getting it & 6.2 & 0.7 & 5.1 & 1.0 & 4.1 & 1.2 & .2 .1 & 1,2 & $-0,9$ & 1,5 \\
\hline 41 Taking politically unpopular action when needed & 6.3 & 0.7 & 5.2 & 1.2 & 4.2 & 1,7 & .2 .1 & 1,7 & $-0,9$ & 2.1 \\
\hline 49 Doing their homework thoroughly & 6.4 & 0.6 & 5.4 & 0.9 & 4.4 & 1.3 & -2.0 & 1,3 & -1.0 & 1,6 \\
\hline 37 Being always properly prepared for meetings & 6.5 & 0.6 & 5.5 & 1.0 & 4,3 & 1.5 & -2.1 & 1.4 & -1.2 & 1,7 \\
\hline & & & & & & & & & & \\
\hline Board capacity & 6,5 & 0,5 & 5,7 & 0,7 & 4,8 & 1,1 & $-1,6$ & 1,1 & $-0,8$ & $\overline{1,2}$ \\
\hline 23 Being balanced in composition (e.g. financial. legal) & 5.3 & 0.8 & 5.0 & 1.0 & 4,7 & 1.2 & -1.6 & 1,3 & -0.3 & 1,5 \\
\hline 34 Having members with expert financial knowledge & 5.1 & 1.0 & 5,2 & 1.1 & 4,8 & 1.4 & $-1,3$ & 1.5 & -0.4 & 1,5 \\
\hline $\begin{array}{l}33 \text { Displaying impeccable integrity \& honesty e.g. own } \\
\text { claims }\end{array}$ & 6.9 & 0.3 & 6,4 & 0,8 & 5,4 & 1,5 & $-1,4$ & 1.5 & -1.0 & 1,4 \\
\hline 52 Avolding conflict with personal interests & 6.6 & 0.7 & 5.9 & 1,1 & 4.9 & 1.5 & -1.7 & 1,5 & $-1,0$ & 1,6 \\
\hline 22 Disallowing each other private, conflicting agendas & 6.5 & 0.7 & 5.7 & 1.2 & 4.6 & 1.4 & $.1,9$ & 1,3 & -1.1 & 1,6 \\
\hline & & & & & & & & & & \\
\hline Assurance & 6,3 & 0,5 & 5,2 & 0,8 & 4,4 & 1.1 & $.1,9$ & 1,2 & $-0,8$ & 1,4 \\
\hline $\begin{array}{l}19 \text { Delivering tangible benefits by knowing important } \\
\text { peoole }\end{array}$ & 5,6 & 1.4 & 4,5 & 9,5 & 4,3 & 1,5 & $-1,4$ & 2,0 & $-0,2$ & 2,0 \\
\hline 21 Providing adequate networking & 6.0 & 0.8 & 4.8 & 1.1 & 4,3 & 1.2 & $-1,7$ & 1.2 & $-0,5$ & 1,5 \\
\hline $\begin{array}{l}11 \text { Making the stakeholders feel safe with their } \\
\text { governance }\end{array}$ & 6,6 & 0.7 & 5.5 & 1,2 & 4,6 & 1.4 & $-2,0$ & 1.5 & $-0,9$ & 1,8 \\
\hline 30 Adding value through their strategic guidance & 5.6 & 0,5 & 5,3 & 0,9 & 4,2 & 1,3 & $-2,3$ & 1,3 & -1.0 & 1,7 \\
\hline 10 Having the confidence of stakeholders & 6.5 & 0,6 & 5.7 & 0.8 & 4,5 & 1.4 & $-2,1$ & 1,3 & $-1,2$ & 1,5 \\
\hline Responsiveness \& reliability & 6,3 & 0,5 & 5,0 & 0.9 & 4,2 & 1,2 & .2 .1 & 1.2 & $-0,9$ & $\overline{1,5}$ \\
\hline 8 Willingness to help stakeholders & 6.1 & 0,9 & 4.9 & 1.1 & 4,7 & 1,3 & $-1,4$ & 1,3 & $-0,2$ & 1.4 \\
\hline Readiness to respond to stakeholders' requests & 5.0 & 0.8 & 4.8 & 1.1 & 4.4 & 1.3 & $-1,6$ & 1.3 & $-0,3$ & 1,4 \\
\hline Providing the governance service at the right time & 5.2 & 0.8 & 4.8 & 1,2 & 4.0 & 1.5 & -2.2 & 1,6 & $-0,8$ & 1,9 \\
\hline Deoendability in handling stakeholders' problems & 6.4 & 0.8 & 4.9 & 1.2 & 4.0 & 1.5 & $-2,4$ & 1,5 & $-0,9$ & 1,7 \\
\hline 7 Promotness in taking governing action & 6.5 & 0.6 & 5.2 & 1,1 & 4,2 & 1.5 & -2.3 & 1,5 & $-1,1$ & 1,8 \\
\hline 18 Governing continually and not only when convenient & 5.3 & 0.7 & 5.0 & 1.3 & 4.0 & 1.4 & -2.3 & 1.5 & $-1,1$ & 1.9 \\
\hline 13 Having the knowledge to govern optimally & 6.6 & 0.6 & 5.5 & 0.9 & 4.0 & 1,6 & -2.5 & 1,7 & -1.5 & 1,8 \\
\hline & & & & & & & & & & \\
\hline ECGSI overall mean scoros & 6.3 & 0,4 & 5,3 & 0,8 & 4,4 & 1,0 & $-1,9$ & 1,0 & $-0,9$ & 1,2 \\
\hline $\begin{array}{l}\text { Numbers refer to the question numbers in the origina } \\
\text { instrument and are provided for reference purposes }\end{array}$ & & & & & & & & & & \\
\hline
\end{tabular}

